\title{
The Chronology of Oral Tradition
}

\section{Quest for a Chimera}

\section{David P. Henige}

Chronology is probably the weakest aspect of oral historical materials. The author discusses the various processes by which oral chronology can be distorted and explains the circumstances which promote and facilitate distortion, arguing that the data are not susceptible to quantification. $\mathbf{£ 4 . 7 5}$ Oxford Studies in African Affairs

\section{Pan-Africanism and Nationalism in West Africa 1900-1945}

\section{A Study in Ideology and Social Classes}

\section{J. Ayodele Langley}

This is the first detailed study of the origins of Pan-African politics in West Africa and also of Nationalist and social classes there during the inter-war period. Of particular interest are the author's rediscovery of the francophone African contribution to PanAfricanism, and his analysis of the reception of Black American ideologies in West Africa. $£ 6.50$ Oxford Studies in African Affairs

\section{Ethiopia}

\section{Anatomy of a Traditional Polity}

\section{John Markakis}

This account of the complex interactions between the traditional and the modern elements in the polity and society of Ethiopia concentrates on the historical, cultural, social, and economic forces that determine the distribution and uses of political power. The long and controversial reign of Haile Selassie is astutely analysed. $£ 6.50$ Oxford Studies in African Affairs

\section{Ohaffia}

\section{A Matrilineal Ibo People}

\section{Philip O. Nsugbe}

This is an ethnographic study of a frontier Ibo people in south-eastern Nigeria whose social organization differs significantly from the more familiar forms found among the main Ibo groupings. The emphasis is on distinctive elements of Ohaffia kinship and marriage. £2.10 Oxford Monographs on Social Anthropology 


\section{Gods and Heroes}

\section{Oral Tradition of the Gurage of Ethiopia}

\section{Translated and edited by William A. Shack and Habte-Mariam Marcos}

This collection of praise chants to gods and warrior-heroes stresses the sociological and literary themes through which are manifested the underlying assumptions the Gurage hold about man, nature, the spirit world, and the universe of things. It also illustrates the range of stylistic creativity in Gurage literary prose. $£ 3.75$ Oxford Library of African Literature

\section{An Introduction to the History of Central Africa}

\section{A. J. Wills}

This replaces the second edition published five years ago. The sections on pre-history and the Iron Age in Mashonaland have been revised in the light of recent research, and a new final chapter discusses developments in Rhodesia and Zambia since 1965. Third edition $£ 4$ paper covers $£ 2.50$

\section{African Encyclopedia}

This is a single-volume encyclopaedia centred on subjects of African interest. Each African country has its own article, and there are separate articles on African peoples, languages, historic empires, and on contemporary writers, artists, and leading political figures. A very wide range of subjects is treated from an African viewpoint. Illustrated $f 4$ paper covers $£ 1.50$

\section{An Introduction to Benin Art and Technology}

\section{Philip J. C. Dark}

This book provides the first brief, comprehensive introduction to the art of Benin and the craft of the Edo artist. It reviews the history of the development of the art from the fifteenth century to the present and discusses some of its masterpieces from a Western point of view before considering the context in which the art is produced. Illustrated $£ 8.50$

\section{Fort Jesus}

\section{A Portuguese Fortress on the East African Coast}

\section{James Kirkman}

Fort Jesus, Mombasa, is the most remarkable historical monument on the coast of

Kenya. It was built by the Portuguese in 1593 and has retained its ground plan unchanged since 1636. This is an account of what was found during excavations between 1958 and 1971. The most striking features are the passages leading down to the outwork and the sea front, and a collection of sketches of ships and other subjects on the plastered wall of one of the bastions. Illustrated $\mathfrak{1 1 2 . 5 0}$ 


\section{Black Slaves in Britain}

\section{F. O. Shyllon}

By a careful reconstruction of legal cases and an examination of the attitudes and personalities of many of the figures involved, the author demonstrates how acceptable slavery was in Britain near the turn of the eighteenth century. He shows also that it was economic rather than moral considerations that led ultimately to the abolition of slavery.

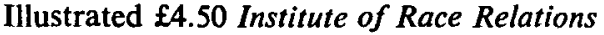

\section{Chronology of African History}

\section{G. S. P. Freeman-Grenville}

This is a comprehensive chronology in tabular form, setting out the known or approximate date of every important event in African history between c. $1000 \mathrm{BC}$ and 31

December 1971. It enables the reader to see at a glance the course of events in different regions of Africa, as well as the main events in the rest of the world. $£ 5$

\section{Railways and the Copper Mines of Katanga}

\section{S. E. Katzenellenbogen}

Big business and the Governments of Belgium, Britain, Germany, France, Portugal, and South Africa became involved in the Katanga copper mines and in the railways built to link them to coastal ports. Individuals exerted great influence on the course of events, most prominently Robert Williams, whose vision and tenacity of purpose made possible the completion of the Benguela Railway against tremendous odds. $£ 3.75$ Oxford Studies in African Affairs

\section{Pan-Africanism from Within}

\section{Ras Makonnen}

\section{Edited by Kenneth King}

Ras Makonnen was born George Nathaniel Griffith in British Guiana at the beginning of this century. This is his account of pan-Africanism, as conceived in the thirties and forties. It is a personal record, for Makonnen took part, together with people like Padmore Nkrumah, in regenerating pan-Africanism; he feels its failure deeply, though he still has faith in the possibility of a United Africa. Illustrated $£ 2.25$ OUP East Africa

\section{The Sword of Truth}

\section{The Life and Times of the Shehu Usuman Dan Fodio}

\section{Mervyn Hiskett}

In the late 18 th and early 19 th centuries, an Islamic revolutionary movement arose in Hausaland that was to transform both government and society in that region. At its centre was Shehu Usuman Dan Fodio, whose views and achievements continue to influence life in present day Nigeria. Illustrated $£ 3.45$ paper covers $£ 1.10$ OUP New York

\section{Source Material on the South African Economy 1860-1970}

Volume 3 1920-1970

\section{Edited by D. Hobart Houghton and Jenifer Dagut}




\section{FRANK CASS}

\section{LION RAMPANT}

Essays in the Study of British Imperialism

D. A. LOW

Australian National University

Studies in Commonwealth Politics and

History Series, 248 pages, $£ 3.00$

\section{WAR AND SOCIETY IN AFRICA}

Ten Studies

Edited by BETHWELL A. OGOT University of Nairobi

276 pages, $\mathbf{f} 4.00$

\section{POLITICAL CHANGE}

Collected Essays

DAVID E. APTER

Yale University

255 pages, $€ 3.75$

\section{THE AFRICAN SLAVE}

\section{TRADE AND ITS}

\section{SUPPRESSION}

A Classified and Annotated Bibliography of Books, Pamphlets and Periodical

Articles

PETER C. HOGG

427 pages, $€ 12.50$

\section{MISSIONARY TO}

\section{TANGANYIKA 1877-1888}

The Writings of Edward Coode Hore, Master Mariner

Edited by JAMES B. WOLF University of Colorado

Missionary Studies Series, 200 pages, £3.15

\section{AFRICA AND WORLD PEACE}

GEORGE PADMORE

With a new introduction by W. M. Warren

Second edition, 305 pages, $\mathbf{f 4 . 0 0}$
MISSIONARY

ENTERPRISE AND

RIVALRY IN IGBOLAND

1857-1914

F. K. EKECHI

Kent State University

Missionary Studies Series, 304 pages, $£ 4.00$

CHINA AND AFRICA IN THE MIDDLE AGES

TEOBALDO FILESI

Translated by David L. Morison

112 pages, illustrated, $£ 2.50$

POLITICS AND SOCIETY

IN SOUTH EASTERN

NIGERIA 1841-1906

A Study of Power, Diplomacy and

Commerce in Old Calabar

KANNAN K. NAIR

University of Malaya

342 pages, maps, illustrated, $£ 5.00$

THE BERBERS

Their Social and Political Life

ROBERT MONTAGNE

147 pages, maps، bibliography, $£ 2.75$

GAZETTEERS OF NORTHERN NIGERIA

Edited by A. H. M. KIRK-GREENE

St. Antony's College, Oxford

Vol. 1 : The Hausa Emirates

232 pages, $£ 6.00$

Vol. 2: The Eastern Kingdoms 260 pages, $£ 5.00$

Vol. 3: The Central Kingdoms 272 pages, $£ 6.00$

Vol, 4: The Highland Chieftaincies 372 pages, $£ 7.00$ 


\section{LIBYA}

Agriculture and Economic Development

Edited by J. A. ALLAN,

K. S. MCLACHLAN

School of African \& Oriental Affairs \&

EDITH PENROSE

University of London

240 pages, 8 maps in slip-case, Photo-

graphs, tables, $£ 7.50$

\section{STUDIES IN THE}

HISTORY OF THE NEAR

\section{EAST}

P. M. HOLT

University of London

269 pages, $€ 4.00$

\section{THE SOUTHERN SUDAN}

The Problem of National Integration

Edited by DUNSTAN M. WAI

250 pages, £3.75

\section{MOROCCO UNDER COLONIAL RULE}

French Administration of Tribal Areas

1912-1956

ROBIN BIDWELL

University of Cambridge

355 pages, $£ 7.50$

\section{NORTHERN AFRICA}

Islam and Modernization

Edited by MICHAEL BRETT

University of London

183 pages, £3.50

\section{UNITED KINGDOM}

PUBLICATIONS AND

THESES OF AFRICA

\section{$1967 \& 1968$}

Standing Conference on Library Materials on Africa

254 pages, $\mathbf{E 3 . 5 0}$

\section{MIDDLE EASTERN}

\section{THEMES}

Papers in History and Politics

JACOB M. LANDAU

Hebrew University of Jerusalem

300 pages, $£ 3.75$

\section{Reprints}

\section{KENYA}

NORMAN LEYS

With a new introduction by George

Shepperson

4th edition, 237 pages, $£ 7.00$

RECORDS RELATING TO

THE GOLD COAST

SETTLEMENTS FROM

1750 to 1874

MAJOR J. J. CROOKS

New impression, 569 pages, $£ 10.50$

\section{THE YOAS}

Chikala Cha Wayao

YOHANNA B. ABDULLAH

Translated by Meredith Sanderson.

with a new introduction by $E$. A. Alpers

New edition, 132 pages. $£ 4.50$

Forthcoming

GOVERNMENT AND

LABOUR IN KENYA

1895-1963

A. CLAYTON \& D. C. SAVAGE

480 pages, maps, Approx. $£ 9.00$

AFRICAN KINGSHIPS IN PERSPECTIVE

Political Change and Modernization in Monarchical settings

RENE LEMARCHAND

University of Florida

348 pages, Approx. $€ 7.00$

If you wish to be placed on our mailing list, or receive our new catalogues write to:

FRANK CASS \& COMPANY LTD. 67 Great Russell Street, London WC1B 3BT 


\section{Colonialism in Africa 1870-1960}

Volume V: A Bibliographical Guide to Colonialism in Sub-Saharan Africa

\section{Edited by PETER DUIGNAN and L. H. GANN}

A major work of bibliographic reference for all researchers concerned with the historical, political, sociological and related problems of colonialism in Africa from about 1870 to 1960 . The remarkable range of written material produced during the colonial period is reflected in the wide range of subjects covered : anthropology, law, economics, religion, geography, linguistics, ethnography, as well as such subjects as biology, botany, medicine, natural science and geology. The inter-disciplinary character will make this a unique and indispensable guide for all specialists in colonial Africa.

$\$ 9.00$ net

INTERNATIONAL STUDIES

\section{China's Policy in Africa 1958-1971}

\section{ALABA OGUNSANWO}

A meticulously researched and incisive examination of a subject which has often been submerged in propaganda. Dr Ogunsanwo traces in great detail the phases and development of Chinese policy in Africa, diplomatic, military, economic, social and cultural relations over the whole of the continent from 1958 to 1971 . He concludes with a discussion of Nixon's visit to Peking and its implications for Africa.

f6.50 net

\section{AFRICAN STUDIES SERIES 11}

\section{Islam and Tribal Art in West Africa}

\section{RENÉ A. BRAVMANN}

Most writers have assumed that the spread of the Islamic faith has tended to weaken and undermine the foundations of traditional African society and culture. In this interesting and original study Dr Bravmann re-examines and refutes the assumption that the aniconic attitudes of Islam, especially the prohibition of representational imagery, have had a detrimental effect on the visual arts in the areas of West Africa influenced by this universalistic faith.

\section{Now in paperback}

$$
46 \text { plates } \$ 5.00 \text { net }
$$

\section{A History of the Maghrib}

\section{JAML M. ABUN-NASR}

'The appearance of the first complete history of North Africa in English is an important event.'

\section{Bulletin of the School of Oriental and African Studies}

'Professor Abun-Nasr's study is unique; it is the only book in English which attempts to describe the history of the Maghrib from prehistoric times to the achievement of independence in the mid-rgoos ... This work can be recommended as a good, detailed introduction to the history of the Maghrib.'

Fournal of Developing Areas

Paperback- $\$ 2.00$ net

\section{CAMBRIDGE UNIVERSITY PRESS}




\section{Zamani : NewEdition}

\section{A Survey of East African History}

\section{Edited by B A Ogot}

A revised and up-dated edition of this important survey, in which eighteen leading historians combine the results of their individual research into original sources to produce an authoritative account and assessment of the last two thousand years of East African history for Sixth Form and University.

'...........even specialist readers may here find syntheses more up-to-date and occasionally interpretations of greater originality than anything else in print.'

Journal of African History

\section{An Economic History of West Africa}

\section{A G Hopkins}

Recently published, this is the first comprehensive account of the economic history of the huge area conventionally known as West Africa.

'........ a valuable work.' - West Africa

' ......... a remarkable achievement.' - Times Literary Supplement

' This is a most scholarly work, the product of long and painstaking research, which will probably (and deserves to) remain a standard textbook for many years to come.' - Times Higher Educational Supplement

0582645638

Cased $£ 5.00$ net

0582645215

\section{Longman Africana Catalogue 1974/75}

If you would like to receive a complete and up-to-date list of Longman post-school African History books, please complete the form below.

To African Division, Longman Group Ltd., Longman House, Burnt Mill, Harlow Essex, U.K. Please send me a copy of the Longman Africana Catalogue 1974/75, now available Name Position (if any)

Address

I would like to receive regular information about new books, as they are published $\square$ please tick.

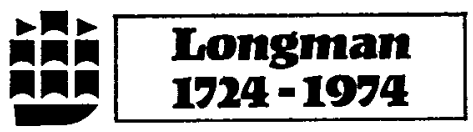




\section{A \\ MICROFILM SERIES \\ OF \\ GOVERNMENT PUBLICATIONS RELATING TO AFRICAN TERRITORIES}

A series of microfilm publications containing government publications relating to African countries will be released over the next six years by EP Microform in conjuction with the African Studies Association of the United Kingdom. The series will cover the periods prior to the independence of the countries, and each publication will contain material designed to provide a comprehensive coverage of Annual Reports, Government Gazettes and statistical Blue Books for each country in addition to other significant documents selected by an editor with expert knowledge of the territory concerned. The series will consist of separate sets of microfilms relating to the following countries:

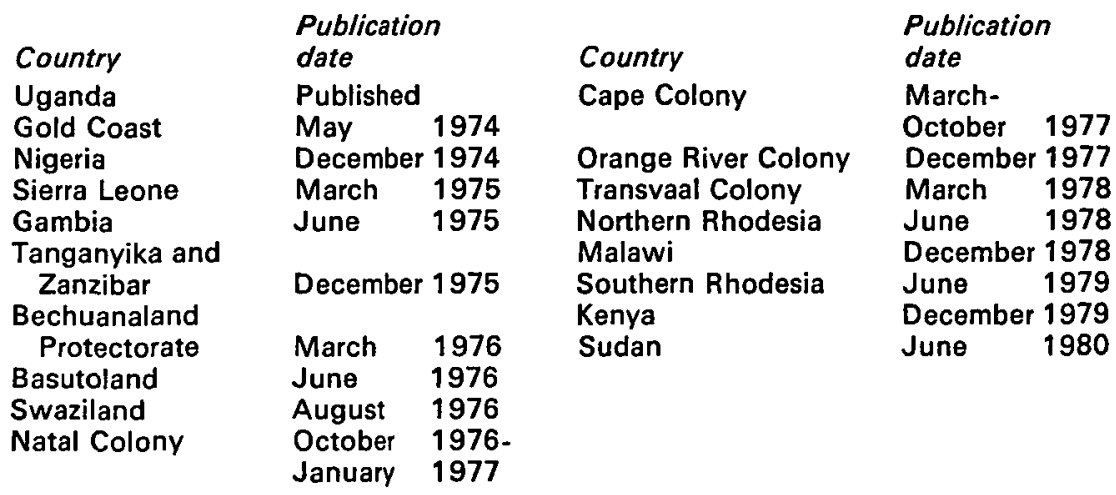

A summary of the contents of each set of microfilms will be available a few months before its publication and a detailed synopsis will also be available prior to its release. Each set of microfilms will be prefaced by an introductory essay written by the editor, and this will be contained in a separate printed pamphlet which will accompany the publication to which it relates. Please write to the address below if you wish to be kept informed of the progress of the series. Those already on the EP mailing list will be informed automatically.

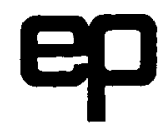

EP Microform Limited

Bradford Road East Ardsley Waketield Yorkshire

WF3 2JN England 
Contributions to the fournal are welcomed. They may be submitted in either English or French. They should not exceed about 6000 words (excluding footnotes), except with the prior approval of the Editors. A summary of the contents of the article, not exceeding about 300 words in length, should be attached on a separate sheet. Contributors are asked to observe closely the conventions listed in the Notes for Contributors, inside the back cover of the last issue. It is essential that contributors observe these conventions, as the fournal now goes straight into page proof. This severely limits the number of corrections which are possible.

Page proofs will be sent, if necessary by airmail, to each contributor (or his nominee) provided that the Editors have been given an address through which he can be reached without delay. Corrections should be kept to the minimum, and should be corrections, not new material. If they are to be incorporated in the master proof corrected by the Editors, it is important that the contributor should return the page proofs, by airmail if necessary, to the Editor named when they are sent out (and not to the Cambridge University Press), within ten days of his receipt of them.

Contributors of articles and review articles receive 25 free separates. Additional separates may be obtained at reasonable cost, provided that they are ordered before publication on the special form sent out with the galley proofs.

All contributions and books for review should be addressed to The Editors, The Fournal of African History, School of Oriental and African Studies, University of London, London, W.C.I.

The Fournal of African History: Volumes 2, 3, and 4

Cambridge University Press apologizes for the delay in publication of Volume XV, Number 2 of the fournal. Unfortunately, Numbers 3 and 4 will also be published later than originally announced, Number 3 appearing in November 1974 and Number 4 in February 1975. It is hoped that Volume XVI (1975) will be published on the usual quarterly schedule. The Press regrets any inconvenience these delays may cause to subscribers. 


\section{CONTENTS}

page

I New radiocarbon dates for Eastern and Southern Africa

By R. C. SOPER (University of Ibadan)

II The ancestry of the Mende: An appraisal of Migeod's argument By Matthew H. Hill (University of Waterloo, Ontario)

III Ano Asemã: Mythe et histoire By Claude-H. Perrot (Université d'Abidjan).

IV The Atlantic Slave Trade: A tentative economic model By Henry A. Gemery and Jan S. Hogendorn (Colby College, Waterville, Maine)

$\mathrm{V}$ The West Indies and British West African policy in the nineteenth century-a corrective comment

By William A. Green (College of the Holy Cross, Worcester, Mass.)

VI Alula, 'The Son of Qubi': a 'King's Man' in Ethopia, I875-1897 By HaggaI ErLICH (Tel Aviv University)

VII The 1912 Wankie Colliery strike

By Charles van Onselen (St. Antony's College, Oxford)

VIII The Italo-Ethiopian conflict: A case study in British West African response to crisis diplomacy in the I93os

By S. K. B. Asante (University of Ghana)

IX Ganda receptivity to change

By Michael Twadde (Institute of Commonwealth Studies, University of London)

\section{COMMENT}

Traditions of Genesis

By Jan Vansina (University of Louvain)

BOOKS REvIEWED

An Economic History of West Africa. By A. D. Hopkins (C. C. Wrigley), 323; Islam et sociétés soudanaises au moyen-âge: étude historique, Recherches voltaïques. By Jean-Louis Triaud (Humphrey J. Fisher), 325; Le royaume du Waalo. Le Sénégal avant la conquete. By Boubacar Barry (CharlotTe Quinn), 326; Old Calabar 1600-189I. The Impact of the International Economy upon a Traditional Society. By A. J. H. Latham (G. I. JoNEs), 328; The New Oyo Empire: Indirect Rule and Change in Western Nigeria 1894-1934. By J. A Atanda (R.C.C.L.), 330; The Kru Mariner in the Nineteenth Century: An Historical Compendium. By George E. Brooks Jr. (Elizabeth Tonkin), 332; The Second World War and Politics in Nigeria 1939-1953. By G. O. Olusanya (A. H. M. Kirk-Greene), 334; Porruguese Settlement on the Zambezi: Exploration, Land Tenure and Colonial Rule in East Africa. By M. D. D. Newitt and Colonialismo e feudalismo: La questione dei Prazos da Coroa nel Mozambico alla fine del secolo XIX. By Giuseppe Papagno(Gerhard Liesegang), 336; Malawi: The History of a Nation. By Bridglal Pachai (John MCCricken), 338; South Africa: an Historical Introduction. By Freda Troup (Colin Bundy), 339; The Boer War Diary of Sol T. Plaatje: an African at Mafeking. Edited by John L. Comaroff (P. L. BonNER), 34I ; Inventario delle Fonti Manoscritte relative alla Storia dell'Africa del Nord esistenti in Italia. Vol. I: Gli archivi storici del soppresso Ministero dell'Africa Italiana e del Ministero degli Affari Esteri, dalle origini al I922. Vol. II: Gli archivi storici del Ministero della Difesa, dalle origini al 1922. Edited by Carlo Giglio, and Guida delle Fonti per la Storia dell'Africa a Sud del Sahara esistenti in Italia. Vol. I. Edited by Carlo Giglio and Elio Lodolini (Richard Gray), 343; Periodiques Malgaches. By J.-C. Poitelon, Germaine Razafintsalama, Rasoahanta Randrianarivelo (J. T. HaRdyman), 345.

SHORTER NOTICES

Studies in the History of the Near East. By P. M. Holt (R. S. O'FAHEY), 348; Foundation of the Cape, and About the Bechuanas. By W. H. C. Lichtenstein (S.M.), 349; The Emin Pasha Relief Expedition 1886-90. By Iain R. Smith, and The Rescue of Emin Pasha. By Roger Jones (CAROLINE Oliver); 350. 